The University of Maine

DigitalCommons@UMaine

$11-2010$

\title{
Home Ranges of Rusty Blackbirds Breeding in Wetlands: How Much Would Buffers from Timber Harvest Protect Habitat?
}

Luke L. Powell

Thomas P. Hodgman

William E. Glanz

Follow this and additional works at: https://digitalcommons.library.umaine.edu/bio_facpub

Part of the Natural Resources and Conservation Commons, and the Ornithology Commons

This Article is brought to you for free and open access by DigitalCommons@UMaine. It has been accepted for inclusion in Biology and Ecology Faculty Scholarship by an authorized administrator of DigitalCommons@UMaine. For more information, please contact um.library.technical.services@maine.edu. 


\title{
HOME RANGES OF RUSTY BLACKBIRDS BREEDING IN WETLANDS: HOW MUCH WOULD BUFFERS FROM TIMBER HARVEST PROTECT HABITAT?
}

\author{
Luke L. Powell ${ }^{1,3}$, Thomas P. Hodgman ${ }^{2}$, and William E. Glanz ${ }^{1}$ \\ ${ }^{1}$ University of Maine, School of Biology and Ecology, Orono, ME 04469 \\ ${ }^{2}$ Bird Group, Maine Department of Inland Fisheries and Wildlife, Bangor, ME 04401
}

\begin{abstract}
We calculated the home ranges and core areas of 13 adult Rusty Blackbirds (Euphagus carolinus) in Maine to determine (1) the area requirements of breeding adults, (2) whether area requirements of the sexes and of colonial and noncolonial individuals differ, and (3) the proportion of the home range and core area that would be protected by a buffer of no logging of 50-100 m around occupied wetlands. Mean home ranges (37.5 $\pm 12.6 \mathrm{ha})$ and core areas (11.1 $\pm 2.8 \mathrm{ha}$ ) were large in comparison to those of other breeding icterids, and adults often foraged in multiple unconnected wetlands. Rusty Blackbirds that were part of a loose colony had home ranges and core areas three times larger than those of pairs that nested solitarily, which we speculate may be due to adults following one other to feed on unpredictable emergences of aquatic insects. Home ranges and core areas included a surprisingly small amount of wetland habitat, only $12 \%$ and $19 \%$ respectively, but adults often foraged in small wet patches $\left(<16 \mathrm{~m}^{2}\right)$ in otherwise upland habitat. The $75-\mathrm{m}$ buffers around wetlands that we recommended in a concurrent study may help protect the Rusty Blackbird's nesting habitat, but such buffers contained less than half the average home range, suggesting that they may be of only limited benefit as a conservation strategy for protecting foraging habitat.
\end{abstract}

Key words: boreal wetlands, Euphagus carolinus, home range, radio telemetry, Rusty Blackbird, wetland buffers.

\section{Uso del Ámbito Hogareño para Evaluar la Utilidad Potencial de Zonas de Amortiguamiento de \\ Cosecha de Madera Alrededor de Humedales en los que Euphagus carolinus se Reproduce}

Resumen. Calculamos el ámbito hogareño y las áreas núcleo de 13 adultos de Euphagus carolinus en Maine para determinar (1) los requerimientos de área de adultos reproductivos, (2) si los requerimientos de área de los sexos y de los individuos coloniales y no coloniales difieren, y (3) la proporción del área de acción y del área núcleo que debe ser protegida por una zona de amortiguamiento sin tala de 50-100 m alrededor de humedales ocupados. Los promedios de los ámbitos hogareños (37.5 \pm 12.6 ha) y de las áreas núcleo (11.1 \pm 2.8 ha) fueron mayores en comparación con los de otros ictéridos reproductivos, y a menudo los adultos forrajearon en múltiples humedales no conectados. Los individuos de E. carolinus que eran parte de una colonia laxa presentaron ámbitos hogareños y áreas núcleo tres veces más grandes que los de aquellas parejas que anidaron de manera solitaria, lo que especulamos se podría deber a que los adultos se siguen los unos a los otros para alimentarse de apariciones impredecibles de insectos acuáticos. Los ámbitos hogareños y las áreas núcleo incluyeron una cantidad sorprendentemente pequeña de hábitat de humedal, sólo un $12 \%$ y un $19 \%$ respectivamente, pero a menudo los adultos forrajearon en pequeños parches húmedos $\left(<16 \mathrm{~m}^{2}\right)$ en hábitats que de otro modo son de tierras altas. Un estudio simultáneo indicó que las zonas de amortiguamiento alrededor de los humedales podrían ayudar a proteger a los nidos de E. carolinus de la depredación. Sin embargo, las zonas de amortiguamiento de $100 \mathrm{~m}$ de ancho alrededor de los humedales de reproducción contuvieron solo la mitad del ámbito hogareño promedio y estuvieron por los tanto limitados en cuanto al tamaño del hábitat de forrajeo que podrían proteger de ser alterados.

\section{INTRODUCTION}

Understanding how animals use landscapes is critical in formulating strategies to conserve their habitats (Storch 1995, Caro 1999, Powell and Bjork 2004). Home range is defined as the area an individual uses during a specific period of its life
(Burt 1943) and can be useful in comprehending a species' social structure, habitat, and area requirements (Bingham and Noon 1997). Understanding home ranges also can be useful for determining the size of buffers necessary to protect important habitats from human disturbance (Milam and Melvin 2001).

Manuscript received 30 July 2010; accepted 11 August 2010.

${ }^{3}$ Current address: Louisiana State University, School of Renewable Natural Resources, Baton Rouge, LA. E-mail: LPowe19@LSU.edu

The Condor, Vol. 112, Number 4, pages 834-840. ISSN 0010-5422, electronic ISSN 1938-5422. @ 2010 by The Cooper Ornithological Society. All rights reserved. Please direct all requests for permission to photocopy or reproduce article content through the University of California Press's Rights and Permissions website, http://www.ucpressjournals.com/ reprintInfo.asp. DOI: $10.1525 /$ cond.2010.100151 
Our understanding of the breeding ecology of the Rusty Blackbird (Euphagus carolinus) has improved markedly since Greenberg and Droege (1999) first publicized the species' decline (Matsuoka et al. 2010a, Powell et al. 2010a), yet we still know little about breeding birds' social organization, area requirements, or how the quality and distribution of foraging habitat affects each of these. Rusty Blackbirds breed exclusively in boreal wetlands, where they occur at low densities, nest predominately in conifers (Matsuoka et al. 2010a, Powell et al. 2010a), and forage on aquatic insect larvae and crustaceans by probing in vegetation in or near shallow water (Forbush 1927, Ellison 1990, Avery 1995). Although breeding Rusty Blackbirds have been commonly observed taking flights of several hundred meters (Machtans et al. 2007, Matsuoka et al. 2010b), there is no prior information on their home ranges. Orians (1985) described the species as loosely colonial, yet there is only one such report from New England (Powell et al. 2010b). Consequently, it is unclear if area requirements vary with social organization.

Powell et al. (2010a) found that when Rusty Blackbirds nested in wetlands with recent timber harvests, they suffered $2.5 \times$ more nest predation than when they nested in wetlands without recent timber harvests. Retaining unlogged buffers in upland habitats around wetlands may help mitigate these negative effects on reproduction (Powell et al. 2010a). Spatial patterns in breeding blackbirds' use of wetlands may reveal the potential for upland habitat buffers around wetlands to minimize disturbance of wetlands in which the birds nest or forage. In this study, we radiotracked adult Rusty Blackbirds during the breeding season in northern Maine to (1) estimate sizes of home ranges and core areas, (2) compare home ranges and core areas by sex and of colonial and noncolonial individuals, and (3) determine the proportion of the average home range and core area that would be protected by buffers of 50 , 75 , and $100 \mathrm{~m}$ of unharvested upland habitat around occupied wetlands.

\section{METHODS}

\section{STUDY AREA}

We captured, marked, and radiotracked Rusty Blackbirds at four sites located between 15 and $28 \mathrm{~km}$ of Moosehead Lake and within industrially managed forests in Somerset and Piscataquis Counties, Maine. Site A was centered on a 70-ha, 13year-old stand of regenerating spruce (Picea sp.) and balsam fir (Abies balsamea) that included a loose colony of Rusty Blackbirds described in detail by Powell (2010b; Fig. 1). This stand contained two 0.6-ha scrub-shrub wetlands (Cowardin et al. 1979), a well-maintained gravel road, and many wet patches of Sphagnum sp. A hill just east of the regenerating stand was covered by a mosaic of older ( $>40$ years) conifers, many recent partial cuts dominated by raspberry brambles (Rubus sp.), and a 1.3-ha forested wetland dominated by northern white cedar snags (Thuja occidentalis).

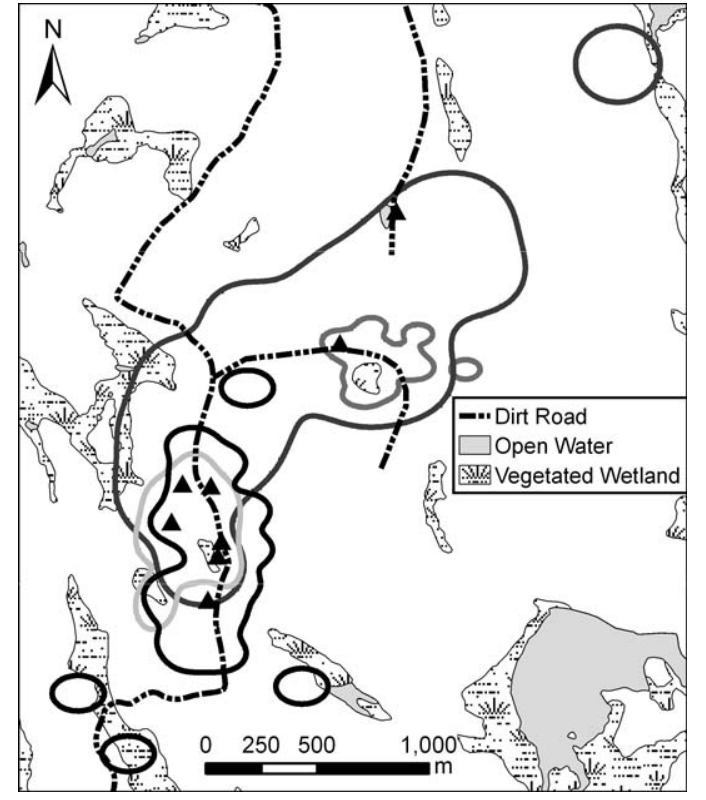

FIGURE 1. Home ranges of four male Rusty Blackbirds at a loose colony, site A, in Maine, 2007. Triangles represent active nests, white space represents forested upland, and polygons of different shades represent individual males' home ranges. Females are not shown, nor are two isolated relocations of the male with the black home range. The two lighter gray polygons did not reach an asymptote.

Site B was centered on three small and shallow vernal pools ( 0.7 ha total, $<20 \mathrm{~cm}$ deep) with gravel bottoms that originated from borrow pits created during road construction (Fig. 2a). Rusty Blackbirds often foraged in these vernal pools, which contained many tadpoles (L. L. Powell, pers. obs.). Wetland vegetation was dominated by speckled alder (Alnus rugosa); the uplands included red spruce (P. rubens), balsam fir, paper birch (Betula papyrifera), and many recent partial cuts.

Site C (Fig. 3) was centered along a 1-m-wide stream that connected a complex of terraced wetlands impounded by beaver (Castor canadensis). An abandoned logging road, overgrown with vegetation, bisected this site. Wetland vegetation included black ( $P$. mariana) and red spruce, speckled alder, and Sphagnum sp. The surrounding forest was composed primarily of 15-year-old regenerating spruce and fir 3-4 m tall.

Site D was centered along a well-maintained and active logging road that bisected the two wetlands regularly used by Rusty Blackbirds (Fig. 2b). South of the road, 16- to 18-yearold spruce and northern white cedar dominated a $>50$-ha regenerating fen with Sphagnum sp. and puddles of open water. North of the road, a 20-m-wide strip of mature spruce, balsam fir, and paper birch buffered a 1-ha emergent and forested wetland. The surrounding forest had been partially harvested within the last three years. 

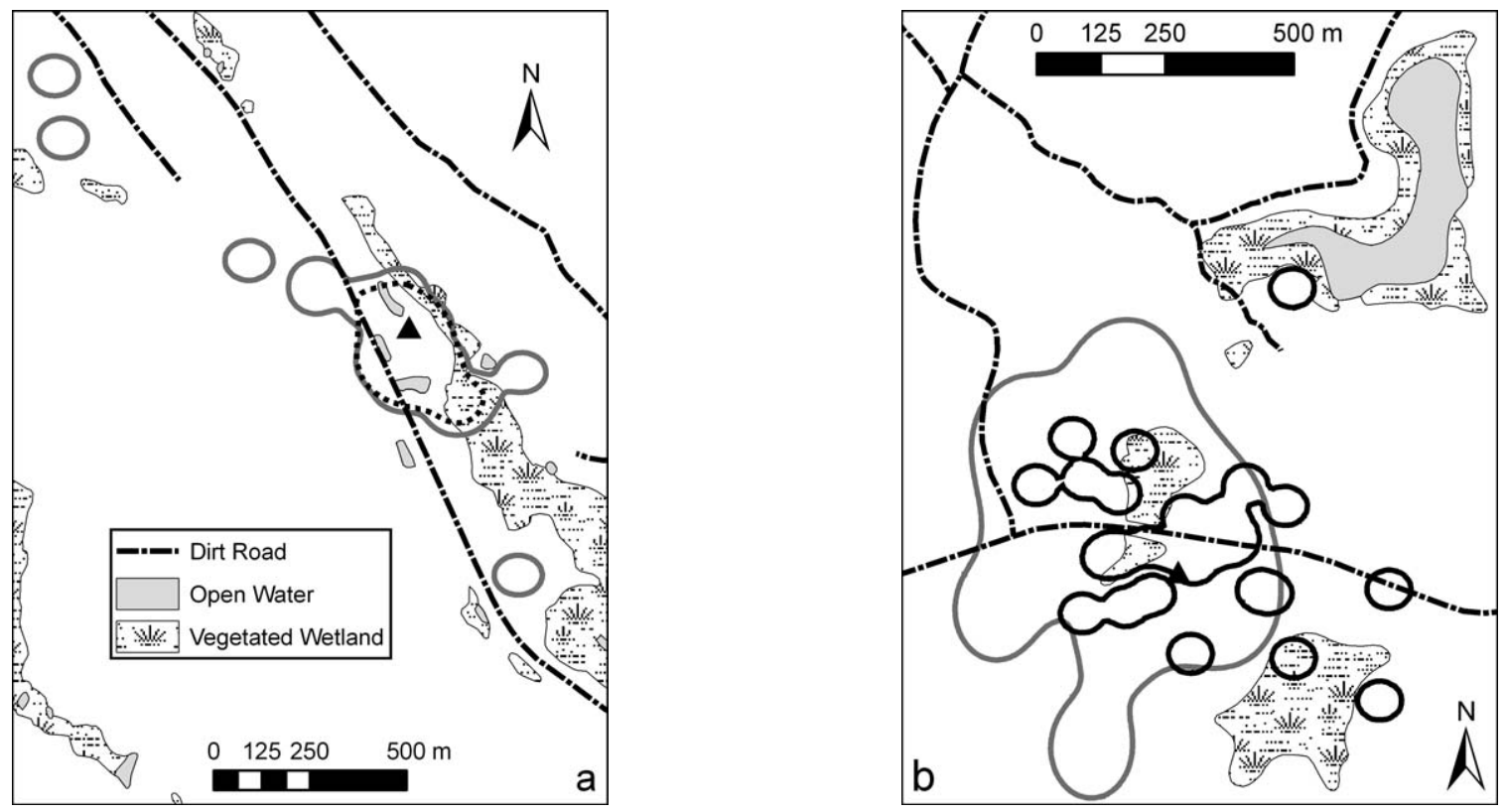

FIGURE 2. Home ranges of three Rusty Blackbirds at (a) site C and (b) site D, in Maine, 2007. Triangles represent active nests, white space represents forested upland, and bold black and gray polygons represent home ranges of one male and two females, respectively. In (a), the dashed-line polygon represents the female's core area $(76 \% \mathrm{KDE})$, and the open water resulted from borrow pits created during road construction. In (b), the male's home range did not reach an asymptote.

\section{RADIO TELEMETRY}

From late May to mid-June 2007, we captured adult Rusty Blackbirds in mist nets placed near nests or wetlands used for foraging (Powell 2008). We banded eight males and seven females each with a U.S. Geological Survey aluminum band and

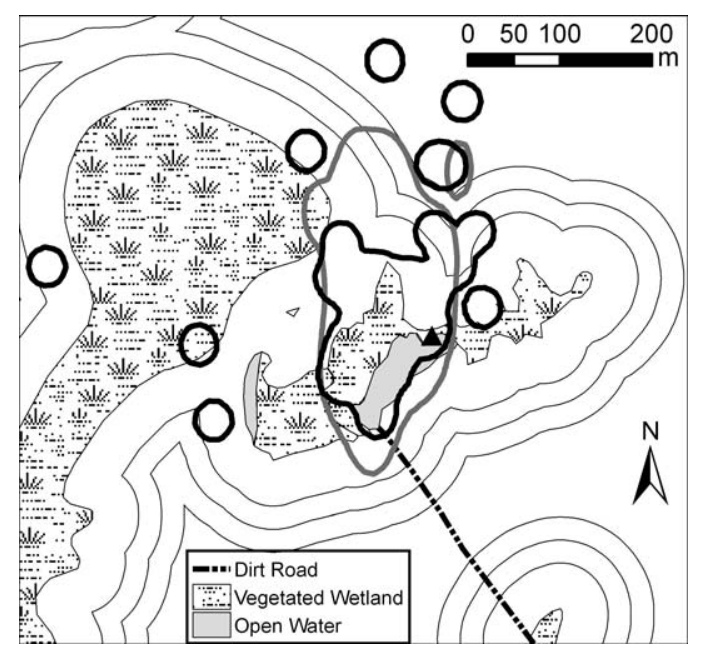

FIGURE 3. Home range of a breeding pair of Rusty Blackbirds at site B, in Maine, 2007. The triangle represents the pair's nest, white space represents forested upland, and gray contour lines represent buffers of 50, 75, and $100 \mathrm{~m}$ around wetlands. Bold black and gray polygons represent the home ranges of the male and female, respectively. a unique combination of colored leg bands. We fitted each bird with a radio transmitter (1.6 $\mathrm{g}$ for females, $1.9 \mathrm{~g}$ for males; $<3 \%$ of body weight) from Holohil Systems Ltd. (Carp, Ontario; model BD-2) by means of a cotton-thread harness (Rappole and Tipton 1991). Following each capture, we waited at least $24 \mathrm{hr}$ before recording locations to allow each bird adequate time to adjust to the transmitter and bands. We relocated the birds from 7 June to 11 July 2007.

We radiotracked each individual for a minimum of 3 nonconsecutive days in a 5-day period. The one exception was a female that we radiotracked intensively for one day $(05: 20-15: 00)$. We included data from this bird in our statistical analyses because her home range reached an asymptote. We categorized the daylight hours into five equal time blocks, randomized which time block to target for a given radio-marked bird, and then relocated the target bird at 10 -min intervals. We chose the latter to provide biological independence of locations by ensuring "a sampling interval long enough to allow the animal to move from any point in its home range to any other point" (Lair 1987:1099). Rusty Blackbirds can fly approximately $5.7 \mathrm{~km}$ in $10 \mathrm{~min}$ (Wood 1933), more than twice as far as the diameter of the largest home range we identified (Fig. 1). Thus our sampling design controlled for diurnal patterns in bird activity over the study period and minimized autocorrelation between consecutive relocations (Otis and White 1999).

During each 10-min interval, two or three technicians each used a hand-held Yagi antenna and simultaneously recorded (1) the compass direction of the strongest radio signal from the bird that they were tracking and (2) the location 
where they received it with a hand-held GPS receiver. Technicians arranged themselves so that bearings were as close to $90^{\circ}$ from each other as feasible and as close to target birds as possible without noticeably affecting behavior. We triangulated bearings with LOCATE III (Nams 2006). We tested for observer error in measuring compass bearings to radiomarked birds by randomly placing a test transmitter in and around wetlands used by radio-marked Rusty Blackbirds. Naïve observers then recorded bearings to the test transmitter by the same techniques described above.

\section{HOME RANGE AND CORE AREA}

We visually inspected each individual's locations in chronological order and then removed locations representing obvious range shifts to meet the assumption that individuals show fidelity to a given area over the course of the sampling period. We estimated $95 \%$ fixed-kernel densities (KDE; referred to hereafter as "home range") with Home Range Tools for ArcGIS (Rodgers et al. 2007). We estimated fixed rather than adaptive kernels on the basis of Seaman and Powell's (1996) conclusion that fixed kernels outperform adaptive kernels. We used the Gaussian (bivariate normal) kernel form and a leastsquares cross-validation for automated bandwidth selection. Kernels had a grid-cell resolution of $10 \mathrm{~m}$, and contouring was performed by volume. We used a scaling factor of 1000000 and rescaled home ranges to unit variance. We calculated core areas for each individual with Powell's (2000) objective and area-independent method (Laver and Kelly 2008) in ABODE for ArcGIS (ESRI 2006, Laver 2006). Rather than arbitrarily using 50\% KDE, we used ABODE to calculate the probability of use for each cell of the KDE and defined the core range as the area in which the probability density was significantly greater than expected by a random distribution.

We used ABODE for ArcGIS (ESRI 2006, Laver 2006) and Laver's (2005) recommendations to determine the number of relocations at which home-range size reached an asymptote. We recalculated each individual's home range after the addition of each randomly added location and repeated this procedure 10 times for each home range. We considered the home range to have reached an asymptote when the confidence interval fell within $20 \%$ of the final home-range size for five consecutive points

\section{BUFFERS AROUND WETLANDS}

We used a digital coverage of the National Wetlands Inventory (NWI; Cowardin et al. 1979) in ArcGIS 9.2 (ESRI 2006) to examine whether buffers around wetlands might be useful for protecting Rusty Blackbird breeding habitat. We first verified the accuracy of the NWI on the ground and then used ArcGIS to add previously unmapped beaver-impounded wetlands to site C (Fig. 3). We then calculated the percentage of each Rusty Blackbird's home range and core area that was encompassed by wetlands alone and by wetlands with buffers of
50,75 , and $100 \mathrm{~m}$ around their perimeters. We selected these three widths (Fig. 3) on the basis of the following justifications: (1) $50 \mathrm{~m}$, because rates of predation on bird nests are highest within $50 \mathrm{~m}$ of habitat edges (Paton 1994); (2) $75 \mathrm{~m}$, because Vander Haegen and Degraaf (1996) reported the effects of predation on forest birds extend $75 \mathrm{~m}$ into riparian buffers in Maine, and because $75 \mathrm{~m}$ was the minimum buffer suggested by Powell et al. (2010a) for breeding Rusty Blackbirds; and (3) $100 \mathrm{~m}$, because 43 Rusty Blackbird nests in northern New England found from 2006 to 2008 were 0-95 m away from wetlands (Powell et al. 2010a).

\section{STATISTICAL ANALYSES}

We log-transformed home range and core area as needed to meet the assumptions of normality (Shapiro-Wilk tests) or equal variances (Levene's tests) and then ran $t$-tests $(\alpha=0.10)$ for equal variances in Program R (R Development Core Team $2009)$ to test for differences in mean home-range and corearea size by sex and coloniality. Similarly, we ran paired $t$-tests for equal variance to test for differences between the sexes in the size of home ranges and core areas of breeding pairs. We present all estimates \pm SE unless otherwise noted.

\section{RESULTS}

We captured and radiotagged 15 adult Rusty Blackbirds for which we recorded 493 relocations at four sites. We calculated home ranges for the 13 individuals ( 6 males and 7 females) for which we had $\geq 25$ relocations ( $\bar{x}=38 \pm 3$ relocations). Individuals pecked at their leg bands for the first few hours after capture, but we did not observe any evidence that leg bands or transmitters impeded the ability of adults to fly, forage, or feed young. We collected 54 bird-days of data: three during incubation, 11 during the nestling stage, 25 during the fledgling stage (defined as $\leq 6$ days after fledging), and 15 on one male and one female at site A whose breeding status we could not determine. We excluded all data from 8 to 11 July because family groups began to wander during this time (Palmer 1949) and violate the assumption of site fidelity. Thus, we used only relocations from 7 to 26 June in quantifying home ranges. The mean angular error of triangulated locations on the test transmitter was $13.2^{\circ}$ ( $\mathrm{SD}=9.0, n=38$ bearings).

The mean size of the home ranges of all 13 individuals was $37.5 \pm 12.6 \mathrm{ha}$ (range $3.8-172.8 \mathrm{ha}$ ), and the mean core area was $11.1 \pm 2.8$ ha (range 1.5-34.8 ha). Powell's (2000) method for estimation of the core area produced a mean of $63 \pm 3 \%$ $\mathrm{KDE}$, which was considerably larger than the arbitrary $50 \%$ KDE used in most core-area analyses (Laver and Kelly 2008). Radio-marked birds included an average of $2.8 \pm 0.4$ wetlands within their home ranges and $1.4 \pm 0.3$ wetlands within their core areas. The size of the home range of the four individuals whose home-range size did not reach an asymptote $(\bar{x}=17.7 \pm$ $3.1 \mathrm{ha}$ ) was not statistically different from that of the nine individuals whose home-range size did reach an asymptote 


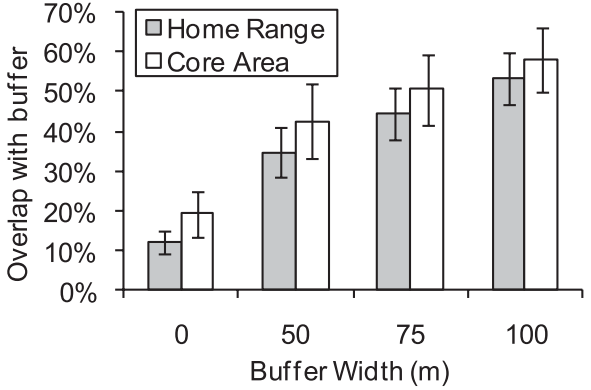

FIGURE 4. The average percentage ( \pm 1 SE) of the $95 \%$ fixed-kernel home ranges and core areas of 13 Rusty Blackbirds that included wetlands and wetlands surrounded by buffers of 50-100 m. Rusty Blackbirds were tracked by radio telemetry on the breeding grounds in Maine, 2007.

$\left(\bar{x}=46.3 \pm 17.6 \mathrm{ha} ; t_{11}=-0.64, P=0.53\right)$. Furthermore, number of relocations to asymptote ( $\bar{x}=31.6 \pm 2.4$ points $)$ was similar to total number of relocations we recorded for the birds for which an asymptote was not reached $(\bar{x}=29.3 \pm 1.4$ points $)$. Because of the similarity in those groups and our small sample size, we pooled data for home ranges that did and did not reach an asymptote.

The sizes of males' home ranges were variable $(\bar{x}=48.0$ ha \pm 26.2 , range 3.8-172.8 ha, $n=6$ ) and not different from that of females $\left(\bar{x}=28.4 \pm 8.1\right.$ ha, range $4.4-71.6$ ha, $n=7 ; t_{11}=$ $-0.11, P=0.91)$. Among breeding pairs $(n=5)$, the mean size of the home range of the male $(\bar{x}=23.1 \pm 8.9$ ha) again was not different from that of the female $\left(\bar{x}=22.0 \pm 4.6 \mathrm{ha} ; t_{4}=0.12\right.$, $P=0.91)$. Size of the core area did not differ by sex for all birds $\operatorname{pooled}\left(\bar{x}_{\text {male }}=12.0 \pm 5.5 \mathrm{ha} ; \bar{x}_{\text {female }}=10.3 \pm 2.6 \mathrm{ha} ; t_{11}=-0.30\right.$, $P=0.77)$ or within pairs $\left(\bar{x}_{\text {male }}=7.4 \pm 3.3 \mathrm{ha} ; \bar{x}_{\text {female }}=8.2 \pm\right.$ 2.0 ha; $t_{4}=-0.17, P=0.87$ ). Home ranges of colonial-nesting birds ( $\bar{x}=51.8 \pm 18.8 \mathrm{ha}, n=8$ ), however, were on average $3.5 \times$ larger than those of noncolonial birds $(\bar{x}=14.6 \pm 5.8$ ha, $n=5$; $\left.t_{11}=-2.5, P=0.03\right)$. The mean size of the core area of colonial birds $(\bar{x}=14.9 \pm 3.8 \mathrm{ha})$ also was $3 \times$ larger than that of noncolonial birds $\left(\bar{x}=4.9 \pm 1.5\right.$ ha; $\left.t_{11}=-2.0, P=0.07\right)$.

The wetlands mapped by NWI encompassed on average only $12 \pm 3 \%$ of home ranges and $19 \pm 6 \%$ of core areas (Fig. 4) However, adding buffers around wetlands increased this area substantially; for example, wetlands with a $75-\mathrm{m}$ buffer encompassed $44 \pm 7 \%$ of home ranges and $51 \pm 9 \%$ of core areas (Fig. 4).

\section{DISCUSSION}

\section{HOME RANGE AND THE EFFECTS OF SEX AND COLONIALITY}

Rusty Blackbirds had mean home ranges and core areas of 37.5 and $11.1 \mathrm{ha}$, respectively, but individuals varied considerably in the amount of space they used (home range 4-179 ha; core area 2-35 ha). Breeding Rusty Blackbirds appear to require more space than breeding Red-winged Blackbirds (Agelaius phoeniceus) or Yellow-headed Blackbirds (Xanthocephalus xanthocephalus), which generally have territories of $<0.6$ ha (Gori 1988, Searcy and Yasukawa 1995; but see Anich et al. 2009). Rusty Blackbirds likely had large home ranges because adults often used multiple wetlands for foraging (range 1-5; Fig. 1-3). We found no difference between the size of males' and females' home ranges or core areas, possibly because of the small sample size or wide variation among individuals.

Despite the variation in space use, home ranges and core areas of Rusty Blackbirds in the loose colony were approximately $3 \times$ larger than those of noncolonial individuals. Horn (1968) suggested that Brewer's Blackbirds (Euphagus cyanocephalus), which also have a variable social organization, nest colonially to take advantage of each other's success in finding spatially and temporally unpredictable emergences of damselflies. Brewer's Blackbirds have relatively small territories (0.05-0.20 ha; Stepney 1971), but like Rusty Blackbirds, may fly up to several kilometers to forage away from their nesting colonies (Fig. 1; Martin 2002, Machtans et al. 2007). Rusty Blackbirds, both colonial and noncolonial, may benefit from flights away from nesting wetlands to feed on ephemeral but rich aquatic insect emergences. Noncolonial birds may have fewer opportunities to learn of such sites on their own. Social interactions may improve foraging efficiency or group defense of nest sites (Powell et al. 2010b) and may help explain the larger home ranges we observed in colonial individuals. More colonies must be located and studied before we can test hypotheses related to colony formation or space use by colonial Rusty Blackbirds.

\section{SAMPLING RECOMMENDATIONS}

The nine of 13 Rusty Blackbird home ranges that reached an asymptote required an average of 32 relocations to do so. This result accords with the recommendation of Seaman et al. (1999) to collect 30-50 points per individual. Although we did not follow Laver and Kelly's (2008) recommendation to include in statistical analyses only home ranges that reached asymptotes, the sizes of the four home ranges that did not reach an asymptote were not statistically different from those that did. Rusty Blackbird studies requiring that all home ranges reach asymptotes should set an a priori goal of at least 50 points per individual or consider calculating asymptotes during the study to confirm when home range sizes stabilize and data collection can cease.

Eleven of 13 Rusty Blackbirds had home ranges larger than 10 ha, and adults often visited wetlands and wet patches not connected to nesting wetlands (Fig. 1, 2b). We doubt that individuals can be effectively tracked over such large areas without telemetry and believe that territory mapping without telemetry would both underestimate the area the species uses (Anich et al. 2009) and underrepresent the potential value of habitats beyond the wetland in which the birds are nesting. Thus, telemetry studies minimize bias in estimates of territory 
size (Anich et al. 2009) and are more useful in identifying habitats appropriate for conservation of this species.

We suspect that home-range size varies with a bird's breeding status, but our small sample limited our ability to test this hypothesis directly. Pairs with fledglings or older nestlings likely have home ranges smaller than those of unpaired birds, as they must meet the constant demand for food by their young. The nine adults we tracked with nestlings or fledglings had relatively small home ranges $(17.0 \pm 3.4 \mathrm{ha})$. Incubating females also probably had relatively small home ranges, but with only three bird-days of data during this stage, we were unable to confirm this. Conversely, unpaired or nonbreeding individuals have more freedom to wander and, thus, should have larger home ranges. The two adults we studied for which breeding status was unknown had the largest home ranges (72 and $173 \mathrm{ha}$ ); we suspect that these individuals were not breeding when we tracked them. We recommend that future telemetry studies of breeding Rusty Blackbirds begin to capture and radiotrack adults in early May when nest building begins (Avery 1995). An early start will provide researchers with the opportunity to better quantify how space use varies across the entire breeding season.

\section{EVALUATION OF BUFFERS FOR HABITAT PROTECTION}

The Rusty Blackbird is considered an obligate wetland breeder (Avery 1995); in New England its site occupancy is best predicted by shallow, independent pools of water (Powell 2008). We were therefore surprised that upland habitats constituted $88 \%$ of home ranges and $81 \%$ of core areas in this study. These high percentages could be due to errors in triangulation or an artifact of fixed KDE smoothing when the home ranges were calculated (Silverman 1986). However, we often observed Rusty Blackbirds foraging in small wetlands such as wet seeps with patches of Sphagnum sp. and depressions resulting from logging and road construction such as sites of removed stumps, skidder ruts, roadside ditches with alders, and borrow pits. These were often too small $\left(<16 \mathrm{~m}^{2}\right)$ to be delineated as wetlands by NWI, but they appeared to be important foraging habitats for Rusty Blackbirds. Thus, we likely underestimated the importance of wetlands in home ranges because the resolution of NWI was too coarse for us to accurately map many of the smaller wetlands in which the birds foraged.

The effects of timber harvests on breeding Rusty Blackbirds are complex, as logging appears to attract the species by increasing both the number of small water bodies available for foraging and the density of young conifers selected for nesting (Powell et al. 2010a). However, when Rusty Blackbirds nested in regenerating timber harvests that extended into or to the edges of wetlands, they suffered twice the rate of nest predation of pairs nesting in wetlands without recent logging. In this respect, harvested stands within or adjacent to wetlands may act as ecological traps (Powell et al. 2010a). Of 43 nests found by Powell et al. (2010a), 29 were within wetlands, and the 14 in uplands averaged only $19 \mathrm{~m}$ from wetlands. A $75-\mathrm{m}$ buffer of no logging around wetlands would clearly encompass most nests and thus likely minimize nest predation (Powell et al. 2010a). Nevertheless, 75-m buffers and their wetlands encompassed an average of only $51 \%$ of core areas and completely encompassed the core area of only three of 13 individuals. The Rusty Blackbird's mobility, coupled with its use of small and perhaps ephemeral wetlands, likely explains this. Therefore, the 75-m-wide buffers recommended by Powell et al. (2010a) to protect nesting habitat may be of only limited benefit as a conservation strategy for protecting foraging habitat. Fortunately, Rusty Blackbirds appear flexible in their use of areas with surface water for foraging, so buffers may be best suited for protecting nesting habitat; however, more research is needed to determine if disturbed and undisturbed foraging habitats are equally suitable.

Landscapes that maximize the Rusty Blackbird's fitness likely contain combinations of wetlands with patches of shallow water that are rich in aquatic prey and undisturbed wetlands with small conifers for safe nesting (Batáry and Báldi 2004, Powell et al. 2010a). The challenge ahead is to implement meaningful conservation measures that accommodate the species' requirement for a large area, need for wetlands that are appropriately buffered from the effects of nest predators, and protection from other potential limiting factors such as high exposures to methylmercury (Edmonds et al. 2010). Time for implementing such measures is short, particularly in New England and southern Canada, where Rusty Blackbirds are rare and the breeding range is retracting quickly (Powell 2008, Greenberg et al., in press; Maritime Breeding Bird Atlas, unpubl. data).

\section{ACKNOWLEDGMENTS}

We thank J. D. Osenton, R. T. Jones, and C. Holmberg for their tireless work as field technicians. We thank B. Tyne, D. M. Ellis, and S. T. Edmonds their contributions in the field, C. Mettke-Hoffman for assistance with radio transmitters, and P. N. Laver for help with ABODE. We extend our gratitude to N. M. Anich, J. C. Bednarz, E. E. DeLeon, R. L. Holberton, C. S. Loftin, and S. M. Matsuoka for insightful reviews. The Maine Warden Service and Russell Pond Bear Hunting Camp provided critical logistical support. Generous funding and support was provided by the Maine Outdoor Heritage Fund, the U.S. Fish and Wildlife Service's Division of Migratory Bird Management, and Federal Aid in Wildlife Restoration. This study was conducted in association with the International Rusty Blackbird Working Group.

\section{LITERATURE CITED}

Anich, N. M., T. J. Benson, And J. C. Bednarz. 2009. Estimating territory and home-range sizes: do singing locations alone provide an accurate estimate of space use? Auk 126:626-634.

Avery, M. L. 1995. Rusty Blackbird (Euphagus carolinus), no. 200. In F. B. Gill AND A. Poole [EDS.], The birds of North America. Academy of Natural Sciences, Philadelphia.

BATÁRY, P., AND A. BÁLDI. 2004. Evidence of an edge effect on avian nest success. Conservation Biology 18:389-400. 
Bingham, B. B., AND B. R. Noon. 1997. Mitigation of habitat "take": application to habitat conservation planning. Conservation Biology 11:127-139.

BURT, W. H. 1943. Territoriality and home range concepts as applied to mammals. Journal of Mammalogy 24:346-352.

CARO, T. 1999. The behavior-conservation interface. Trends in Ecology and Evolution 14:366-369.

Cowardin, L. M., V. Carter, F. C. Golet, and E. T. Laroe. 1979. Classification of the wetlands and deepwater habitats of the United States. U. S. Fish and Wildlife Service, Biological Services Program (FWS/OBS-79/31), Washington, DC.

Edmonds, S. T., D. C. Evers, N. J. O'Driscoll, C. MettKe-Hofmann, L. L. Powell, D. Cristol, A. J. Mcgann, J. W. Armiger, O. Lane, D. F. Tessler, ANd P. Newell. 2010. Geographic and seasonal variation in mercury exposure of the declining Rusty Blackbird. Condor 112:789-799.

ELLISON, W. G. 1990. The status and habitat of the Rusty Blackbird in Caledonia and Essex counties. Vermont Fish and Widlife Department, Woodstock, VT.

ESRI. 2006. ArcGIS, version 9.2. Environmental Systems Research Institute, Redlands, CA.

ForBush, E. H. 1927. Birds of Massachusetts and other New England states, Part 2. Massachussetts Department of Agriculture, New York.

GORI, D. F. 1988. Colony-facilitated foraging in Yellow-headed Blackbirds: experimental evidence for information transfer. Ornis Scandinavica:224-230.

Greenberg, R., And S. Droege. 1999. On the decline of the Rusty Blackbird and the use of ornithological literature to document long-term population trends. Conservation Biology 13:553-559.

Greenberg, R., D. W. Demarest, S. M. Matsuoka, C. MettKeHofmann, M. L. Avery, P. J. Blancher, D. C. Evers, P. B. Hamel, K. A. Hobson, J. Luscier, D. K. Niven, L. L. Powell, AND D. SHAW. 2011. Understanding declines in Rusty Blackbirds. Studies in Avian Biology, in press.

HoRN, H. S. 1968. The adaptive significance of colonial nesting in the Brewer's Blackbird (Euphagus cyanocephalus). Ecology 49:682-694.

LAIR, H. 1987. Estimating the location of the focal center in red squirrel home ranges. Ecology 68:1091-1101.

LAVER, P. N. 2005. Cheetah of the Serengeti Plains: a home range analysis. M.S. thesis, Virginia Polytechnic Institute and State University, Blacksburg, VA.

LAVER, P. N. 2006. ABODE version 5: kernel home range estimation from ArcGIS, using VBA and Objects. <http://filebox.vt.edu/ users/plaver/abode/download.html > (3 March 2008).

LAVER, P. N., AND M. J. KeLLY. 2008. A critical review of home range studies. Journal of Wildlife Management 72:290-297.

Machtans, C. S., S. L. Van Wilgenburg, L. A. Armer, and K. A. HoBSON [ONLINE]. 2007. Retrospective comparison of the occurrence and abundance of Rusty Blackbird in the Mackenzie Valley, Northwest Territories. Avian Conservation and Ecology 2:3. <http://www.ace-eco.org/vol2/iss1/art3/> (10 March 2010).

MARTIN, S. G. 2002. Brewer's Blackbird (Euphagus cyanocephalus), no. 616. In F. B. Gill and A. Poole [EDS.], The birds of North America. Birds of North America, Inc., Philadelphia.

Matsuoka, S. M., D. Shaw, and J. A. Johnson. 2010b. Estimating the abundance of nesting Rusty Blackbirds in relation to wetland habitats in Alaska. Condor 112:826-834.

Matsuoka, S. M., D. Shaw, P. H. Sinclair, R. M. Corcoran, N. C. Dau, J. A. Johnson, P. M. Meyers, And N. A. Rojek. 2010a Nesting ecology of the Rusty Blackbird in Alaska and Canada. Condor 112:810-824.

Milam, J. C., AND S. M. Melvin. 2001. Density, habitat use, movements, and conservation of spotted turtles (Clemmys guttata) in Massachusetts. Journal of Herpetology 355:418-427.
Nams, V. O. 2006. Locate III user's guide. Pacer Computer Software, Tatamagouche, NS.

ORIANS, G. H. 1985. Blackbirds of the Americas. University of Washington Press, Seattle, WA.

Otis, D. L., AND G. C. White. 1999. Autocorrelation of location estimates and the analysis of radiotracking data. Journal of Wildlife Management 63:1039-1044.

Palmer, R. S. 1949. Maine Birds. Bulletin of the Museum of Comparative Zoology, Harvard College, Cambridge, MA.

PATON, P. W. C. 1994. The effect of edge on avian nest success: how strong is the evidence? Conservation Biology 8:17-26.

Powell, G. V. N., AND R. D. BJORK. 2004. Habitat linkages and the conservation of tropical biodiversity as indicated by seasonal migrations of Three-wattled Bellbirds. Conservation Biology 18:500-509.

PowelL, L. L. 2008. Habitat occupancy, status, and reproductive ecology of Rusty Blackbirds in New England. M.S. thesis, University of Maine, Orono, ME.

Powell, L. L., T. P. Hodgman, W. E. Glanz, J. D. Osenton, and C. M. Fisher. 2010a. Habitat use and nest survival of Rusty Blackbirds in New England: does timber management adjacent to wetlands create ecological traps? Condor 112:800-809.

Powell, L. L., T. P. Hodgman, W. E. Glanz, J. D. Osenton, and D. M. ElLIS. 2010b. A loose colony of Rusty Blackbirds nesting in northern Maine. Northeastern Naturalist 17, in press.

Powell, R. A. 2000. Animal home ranges and territories and home range estimators, p. 65-110. In L. Boitani and T. Fuller [EDS.], Research techniques in animal ecology: controversies and consequences. Columbia University Press, New York.

R DEVElopment CoRe TEAm. 2009. R version 2.10.0: a language and environment for statistical computing. R Foundation for Statistical Computing, Vienna, Austria. <http://www.R-project.org> (3 March 2010).

Rappole, J. H., AND A. R. Tipton. 1991. New harness design for attachment of radio transmitters to small passerines. Journal of Field Ornithology 62:335-337.

Rodgers, A. R., A. P. Carr, H. L. Beyer, L. Smith, and J. G. Kie. 2007. HRT: home range tools for ArcGIS, version 1.1. Ontario Ministry of Natural Resources, Centre for Northern Forest Ecosystems Research, Thunder Bay, ON.

Seaman, D. E., AND R. A. Powell. 1996. An evaluation of the accuracy of kernel density estimators for home range analysis. Ecology 77:2075-2085.

Seaman, D. E., J. J. Millspaugh, B. J. Kernohan, G. C. Brundige, K. J. RAEDEKE, AND R. A. GITZEN. 1999. Effects of sample size on kernel home range estimates. Journal of Wildlife Management 63:739-747.

Searcy, W. A., And K. YasuKaWA. 1995. Polygyny and sexual selection in Red-winged Blackbirds. Princeton University Press, Princeton, NJ.

Silverman, B. W. 1986. Density estimation for statistics and data analysis. Monographs on Statistics and Applied Probability 26, Chapman \& Hall, London.

STEPNEY, P. H. R. 1971. Range expansion of Brewer's Blackbird and the ecology of new populations in Ontario. M. Sc. Thesis, University of Toronto, Toronto, ON.

Storch, I. 1995. Annual home ranges and spacing patterns of Capercaillie in central Europe. Journal of Wildlife Management 59:392-400.

Vander Haegen, W. M., and R. M. Degraaf. 1996. Predation on artificial nests in forested riparian buffer strips. Journal of Wildlife Management 60:542-550.

Wood, H. B. 1933. Flight speed of some birds. Auk 50:452-453. 